Kārlis Pigēens, Dace Gaile

\title{
Publiskais iepirkums un inovācijas: vai nākotnē iespējama to cieša mijiedarbība?
}

Pētījuma mērķis ir apskatīt publiskā iepirkuma praksi Eiropas Savienībā, esošā tiesiskā regulējuma ietvaru Latvijā, kavējošos faktorus un attīstības iespējas publiskā iepirkuma izmantošanai inovāciju attīstībā.

Lai sekmētu publiskā iepirkuma modernizāciju, kas ņemtu vērā gan valsts pakalpojumu sniedzēju, gan iedzīvotāju, gan tirgus dalībnieku intereses, kas mainījušās tehnoloğiskās un ekonomiskās attīstības ietekmē, Eiropas Savienība 2014. gadā modernizēja publiskā iepirkuma regulējumu, pieņemot jaunas publisko iepirkumu regulējošas direktīvas. ${ }^{1}$ Jaunais regulējums izvirza mērķi publiskā sektora iestādēm - maksimāli stratēǵgiski izmantot publisko iepirkumu, lai veicinātu inovācijas. Inovatīvu produktu, būvdarbu un pakalpojumu iegādei ir svarīga nozīme, lai uzlabotu sabiedrisko pakalpojumu efektivitāti un kvalitāti, vienlaikus risinot svarīgas sociālās problēmas. ${ }^{2}$

Publisko iepirkumu direktīva inovāciju definē šādi: "Inovācija ir jaunas vai būtiski uzlabotas produkta, pakalpojuma vai procesa, tostarp, bet ne tikai, ražošanas, celtniecības vai būvniecỉbas procesa, ieviešana, jaunas tirdzniecības metodes ieviešana vai jaunas organizatoriskas metodes ieviešana uzṇēmējdarbībā, darba vietu organizēšanā vai ārējās attiecībās inter alia, lai palīdzētu atrisināt sabiedrības

1 Eiropas Parlamenta un Padomes Direktīva 2014/23/ES (2014. gada 26. februāris) par koncesijas līgumu slēgšanas tiesību piešķiršanu, Eiropas Parlamenta un Padomes Direktīva 2014/24/ES (2014. gada 26. februāris) par publisko iepirkumu un ar ko atcel Direktivvu 2004/18/EK, Eiropas Parlamenta un Padomes Direktīva 2014/25/ES (2014. gada 26. februāris) par iepirkumu, ko īsteno subjekti, kuri darbojas ūdensapgādes, enerğētikas, transporta un pasta pakalpojumu nozarēs, un ar ko atcel̦ Direktīvu 2004/17/EK.

2 Direktīvas 2014/24/ES 47. apsvērums. 
problēmas vai atbalstītu Eiropa 2020 stratēgiju gudrai, ilgtspējīgai un integrējošai izaugsmei." 3

Lìdzīga inovācijas definīcija sniegta arī Ekonomiskās sadarbības un attīstības organizācijas (ESAO) izstrādātajā rokasgrāmatā par inovācijām - Oslo rokasgrāmatā. Oslo rokasgrāmatas ${ }^{4} 2018$. gada redakcijā definēti četri galvenie inovāciju virzieni:

1. Organizācijas inovācijas (piemēram, attālinātais darbs).

2. Procesa inovācijas (piemēram, mākoṇpakalpojumi, Lielo datu analīzē balstīta lēmumu pien̦emšana).

3. Produkta inovācijas (piemēram, jauni materiāli, tehnoloğijas, programmprodukti).

4. Tirgus inovācijas (piemēram, produkta iepakojums, piegādes veids).

Oslo rokasgrāmata definē arī piekto inovācijas virzienu - ekoinovācijas, kuru mērķis ir ilgtspējīga un atbildīga dabas resursu izmantošana, vienlaikus biznesam attīstot jaunus videi draudzīgus produktus un pakalpojumus. ESAO rokasgrāmatā uzsvērts, ka inovācijas nav tikai biznesa prerogatīva un tās ir iespējamas un nepieciešamas arī publiskajā pārvaldē. ESAO norāda, ka inovācija valsts pārvaldē nozìmē ieviest kaut ko jaunu, lai panāktu ietekmi. Tātad inovāciju raksturo 3 pazimes - jaunums, ieviešana un ietekme.

Publiskajā sektorā inovācijas var attiekties uz iekšējo procesu modernizāciju un efektivitātes paaugstināšanu, jo īpaši uz publiskās pārvaldes digitalizāciju, kā arī uz publisko pakalpojumu ārējās kvalitātes veicināšanu, lai risinātu veselības aprūpes pakalpojumu kvalitātes un pieejamības, sabiedrības novecošanās, klimata pārmaiṇu, energoefektivitātes, izglitības kvalitātes, aprites ekonomikas u.c. problēmas.

Eiropas Savienības Padome un Eiropas Komisija vairākkārt norādījusi, ka Latvija maz iegulda pētniecībā un izstrādē un tai ir ievērojams investīciju deficīts inovācijas jomā.

Lai arī Covid-19 krīzes laiks šķietami nav labvēlīgākais inovācijām, tomēr zinātnieku un uzṇēmēju sniegtais atbalsts valdībai, risinot ar Covid-19 izplatības ierobežošanu saistītās problēmas, liecina, ka inovācijas ir iespējamas arī krīzes situācijā. Covid-19 pandēmijas laikā strauji pieauga pieprasījums pēc inovatīvām tehnologijām un digitālās transformācijas, jo publiskajam sektoram īsā laikā bija jārod risinājumi, kā turpināt nodrošināt veselības un sociālo pakalpojumu sniegšanu, izglītības procesu, valsts pārvaldes darbu u. c. Vienlaikus bija jāsniedz

Direktīvas 2014/24/ES 2. panta 22. punkts. Identiska definīcija arī direktīvas 2014/23/ES 5. panta 13. punktā un direktīvas 2014/25/ES 2. panta 18. punktā.

4 Innovation: Definition, types of innovation and business examples. Pieejams: https://youmatter.world/ en/definition/definitions-innovation-definition-types-examples/ [skatīts 06.02.2021.] 
atbalsts uzṇēmējiem, kuru biznesa aktivitātes bija pilnībā vai daḷēji paralizētas valstī noteikto ierobežojumu dēḷ.

Kaut gan Latvijā ir salīdzinoši labi apstākḷi inovāciju piedāvājumam, nepieciešams uzlabot arī situāciju ar inovāciju pieprasijumu, tostarp veicinot inovācijas iepirkumus publiskajā sektorā un iepirkumus pirmskomercializācijas posmā, tādējādi paātrinot izgudrojumu pārvēršanu jaunos izstrādājumos, pakalpojumos un darba vietās.

\section{Inovācijas iepirkums pirmskomercializācijas posmā}

Publisko iepirkumu tiesiskais regulējums paredz ìpaši elastīgus noteikumus pētniecības un izstrādes pakalpojumu iepirkumiem, nosakot, ka normatīivajos aktos noteiktās formālās procedūras nav jāpiemēro, slēdzot līgumus par pētniecības un izstrādes pakalpojumiem. Ar pētniecību un izstrādi (turpmāk - P\&I) saprot visas darbïbas, kas saistītas ar fundamentāliem un rūpnieciskiem pētījumiem un eksperimentālo izstrādi. Tomēr šis izņēmums nedarbojas, ja vienlaikus:

- labumu no sniegtā pakalpojuma rezultātiem gūs tikai pasūtitājs, kas šos rezultātus izmantos vienīgi savām vajadzībām;

- pasūtītājs pilnībā samaksās par sniegto pakalpojumu. ${ }^{5}$

Šāds izṇēmums no publisko iepirkumu regulējuma noteikts ar mērḳi atvieglot P\&I inovāciju iegādi to pirmskomercializācijas posmā (publiskais iepirkums pirmskomercializācijas posmā - PIPP), proti, pasūtītājam nepieciešamu inovatīvu risinājumu izveidi un izpēti, kā arī prototipu izstrādi un izmēginājuma produktu vai pakalpojumu radīšanu ierobežotā apjomā. Lai piemērotu šo izṇēmumu, pasūtītājs neparedz P\&্ pakalpojuma rezultātu ekskluzīvu izmantošanu tikai savām vajadzībām, bet ar jaunu, inovatīvu risinājumu izstrādi saistītos riskus un ieguvumus dala ar piegādātāju un citiem pasūtìtājiem. Pakalpojuma iegādē pasūtītājam jārīkojas tā, lai izslēgtu nepamatotu valsts atbalstu izstrādātājam, tostarp nodrošinot maksimālu konkurenci, atklātību, godīgumu un iespēju pasūtītājam saņemt vislabāko risinājumu, ko tirgus var piedāvāt. Līgumam par PIPP jābūt uz ierobežotu laiku, un tajā var iekḷaut prototipu izstrādi vai pirmos produktus vai pakalpojumus ierobežotā daudzumā kā testējamus paraugus, bet jaunradīto produktu vai pakalpojumu iegāde lielākā apjomā nav šā līguma priekšmets. ${ }^{6}$

PIPP būtība ir uz konkurenci balstìta izstrāde vairākos posmos un P\&I posma nošķiršana no galaprodukta izvēršanas komerciālā apjomā. Parastie izstrādes

Publisko iepirkumu likuma 3. panta otrā dal̦a, Sabiedrisko pakalpojumus sniedzēju iepirkumu likuma 10. panta otrā dal̦a.

6 Iepirkumu uzraudzības birojs. (2020). Skaidrojums par Publisko iepirkumu likuma izñēmumu. Pieejams: https://www.iub.gov.lv/lv/skaidrojums-par-publisko-iepirkumu-likuma-iznemumu [skatits 06.02.2021.] 


\section{1. attēls. Inovācijas publiskā iepirkuma pirmskomercializācijas posmā}

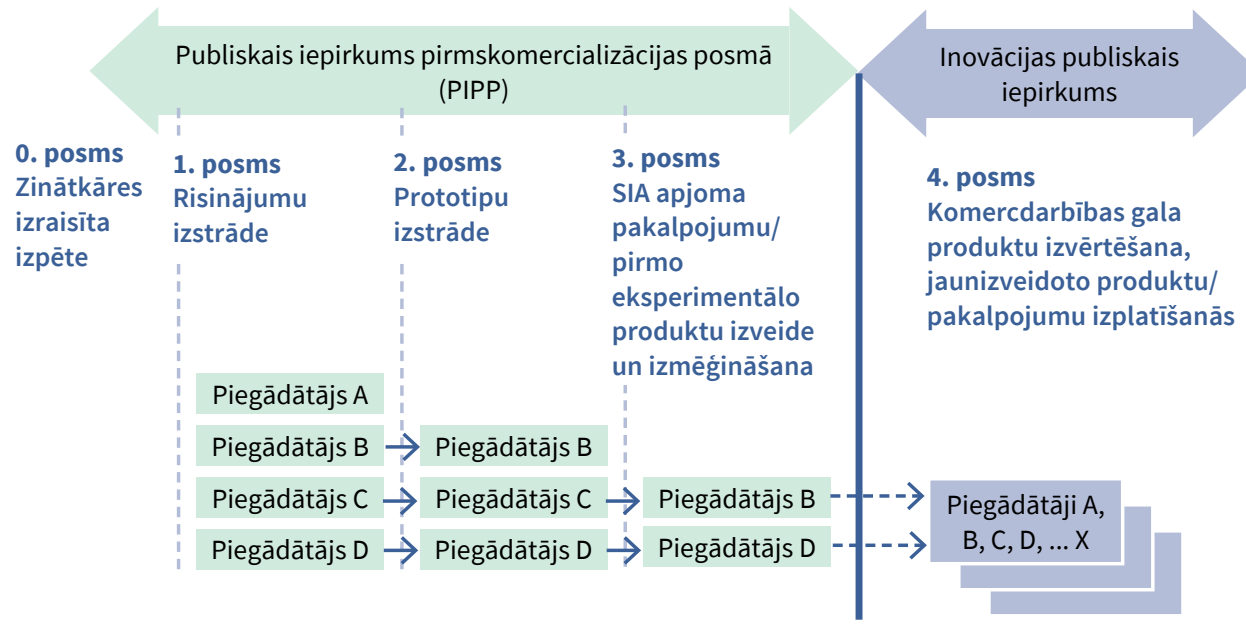

Avots: http://primes-eu.net/media/12191713/07_inovacijas-ieks-zpi_gv.pdf

posmi ir risinājumu izstrāde, prototipu izstrāde, oriǵināla izstrāde un ierobežota pirmo produktu izstrāde/testēšana. Pēc katra P\&I posma tiek samazināts konkurējošo P\&I pakalpojumu sniedzēju skaits, vērtējot un salīdzinot vairākus alternatīvus risinājumus un piemērojot sākotnēji noteiktus izvērtēšanas kritērijus. ${ }^{7}$ Shematiski process atainots 1 . attēlā.

PIPP ir inovācijas iepirkuma pieeja, kas īpaši izstrādāta P\&I pakalpojumu, nevis faktisku preču un pakalpojumu iepirkšanai. Ja nepieciešams iegādāties P\&I posmā izstrādātās preces vai pakalpojumus, tas jādara atseviškāā iepirkuma procesā. PIPP attiecas uz inovatīvu risinājumu iepirkumu, kuri vēl neeksistē tirgū un aptver tikai zinātniski pētniecisko pakalpojumu piegādi. Ar interviju, aptauju un diskusiju starpniecību pasūtītājs identificē iestādes vajadzības un, iesaistot attiecīgo nozaru ekspertus, pārliecinās, ka esošie risinājumi tirgū šīs vajadzības nespēj nodrošināt. PIPP ir sagatavošanās pasākums, kas publiskā iepirkuma veicējiem dod iespēju atklāt alternatīvo risinājumu tehnoloǵiskos pētniecības un izstrādes riskus, pirms tie uzṇemas saistības veikt liela apjoma iepirkumu komerciālai izvēršanai.

Komisijas paziņojums Eiropas Parlamentam, Padomei, Eiropas Ekonomikas un sociālo lietu komitejai un Regionu komitejai. Publiskais iepirkums pirmskomercializācijas posmā. Inovācijas veicināšana ilgtspējīgu kvalitatīvu sabiedrisko pakalpojumu nodrošināšanai Eiropā. COM(2007) 799 galīgā redakcija. Pieejams: https://eur-lex.europa.eu/legal-content/LV/HIS/?uri=CELEX\%3A52007DC0799 [skatīts 08.02.2021.] 
PIPP izvēlas gadijumos, kad:

- būtiski sākuma posmā izvēlēties vairākus piegādātājus, lai atlasītu piemērotākos kandidātus nākamajiem prototipa radīšanas un testēšanas posmiem;

- būtiski samazināt investīciju riskus un paaugstināt konkurētspēju, radot labākus produktus. Kad produkta pirmie izmēginājuma paraugi ir izveidoti, tiek organizēta inovācijas iepirkuma procedūra, kurā to vērtē gan pēc cenas, gan kvalitātes kritērijiem. ${ }^{8}$

Uz PIPP neattiecas Pasaules Tirdzniecības organizācijas Nolīgums par publisko iepirkumu ${ }^{9}$, tāpēc PIPP pasūtîtājam ir tiesības noteikt, ka iepirkumā drīkst piedalīties uzṇēmēji, kuri savu komercdarbỉbu veic tikai Eiropas Ekonomikas zonas dalībvalstīs. Aizsardzības un drošības jomas iepirkumos var tikt izvirzìtas vēl stingrākas prasības.

Eiropas Komisija jau 2007. gadā publicēja rekomendācijas un praktiskus ieteikumus par publisko iepirkumu pirmskomercializācijas posmā ${ }^{10}$, taču Latvijā šis inovāciju attīstības instruments nav guvis plašu atpazīstamību. No Iepirkumu uzraudzības biroja (IUB) apkopotās statistikas izriet, ka 2019. gadā pasūtìtāi ir noslēguši 17 līgumus par P\&I pakalpojumu iegādi par kopējo summu 679352 EUR, taču nedz IUB, nedz Ekonomikas ministrijas rīcībā nav informācijas par pasūtītāju sadarbību ar tirgus dalībniekiem jaunu produktu, pakalpojumu vai tehnologiju izstrādē pirmskomercializācijas posmā.

Vienlaikus vairāku ES dalībvalstu pieredze liecina, ka, realizējot PIPP, var tikt iegūti inovatīvi risinājumi sabiedrībai svarīgu problēmu risināšanā, jo īpaši medicīnas jomā, vienlaikus nodrošinot uzṇēmējiem iespēju attīstìt jauno produktu ražošanu un eksportu.

Piemēram, Polijas Nacionālais P\&I centrs 2020. gada nogalē izsludināja trīs PIPP, tostarp par energoefektīvu un procesu efektīvu mājokḷu būvniecību, kurā jāpiedāvā tehnologijijas saliekamu (2D) vai modulāru (3D) vienǵimenes un daudzǵimeņu ēku būvniecỉbai (jāpiedāvā tehnolog̣iju demonstrācija reālās ēkās) ar zemām būvniecības un ekspluatācijas izmaksām, augstu energoefektivitāti, racionālu ūdens resursu patēriṇu, iespējami lielāku pārstrādāto būvmateriālu

Būtiskākie jautājumi par inovācijas iepirkumu (ES projekts iBuy Interreg Europe.) Pieejams: https://www. interregeurope.eu/fileadmin/user_upload/tx_tevprojects/library/file_1590665261.pdf [skatits 07.02.2021.]

9 WTO. Agreement on Government Procurement. Pieejams: https://www.wto.org/english/tratop_e/gproc_ e/gp_gpa_e.htm [skatits 08.02.2021.]

10 Commission of the European Communities. (2007). Communication from the Commission to the European Parliament, the Council, the European Economic and Social Committee and the Committee of the Regions. Pieejams: https://ec.europa.eu/invest-in-research/pdf/download_en/com_2007_799.pdf [skatìts 08.02.2021.] 
izmantošanu un augstām atkārtotas izmantošanas iespējām gan Polijā, gan aiz tās robežām. ${ }^{11}$

Ir vairāki iemesli, kādēl PIPP Latvijā nav guvis ievērību un netiek izmantots:

1) PIPP iespējas līdz šim tikpat kā nav popularizētas, nav ieteikumu un vadlīniju par procesa organizāciju. Eiropas Parlaments 2009. gada 3. februāra rezolūcijā̄12 aicināja Eiropas Komisiju izveidot vispusīgu, viegli saprotamu juridiski pamatotu rokasgrāmatu visās oficiālajās Eiropas Savienības valodās ar praktiskiem piemēriem, ar kuriem tiktu parādīts, kā praksē pareizi piemērot PIPP, tostarp risku un ieguvumu dalījumu, ipaši paredzot šo rokasgrāmatu mazo un vidējo uzṇēmumu un pasūtītāju lietošanai. Šādu praktisko vadlīniju joprojām nav ne Latvijā, ne Eiropas Savienībā;

2) pasūtītājiem nav pietiekamu zināšanu par P\&I iespējām, trūkst ideju par nepieciešamajām inovācijām;

3) PIPP pēc būtības ir publiskā sektora līdzfinansējums P\&I procesa īstenošanā līdz izmēǵinājuma partijai. Taču jaunradīto preču vai pakalpojumu iepirkumam komerciālā apjomā ir jāorganizē kāda no normatīvajos aktos noteiktajām iepirkuma procedūrām. Tādējādi laiks līdz jauno, inovatīvo preču vai pakalpojumu iepirkumam var būt l̦oti ilgs;

4) uzṇēmèji nav gatavi dalīties ar pētījumu rezultātu, nododot to plašai komercializācijai un zaudējot savas tirgus priekšrocības, ir neskaidrības par intelektuālā īpašuma tiesību sadali;

5) bailes no neveiksmes un kontrolējošo institūciju kritikas.

PIPP veicināšanai ir nepieciešamas praktiskas vadlīnijas un ieteikumi gan pasūtītājiem, gan uzṇēmējiem attiecībā uz digitālas platformas ideju apmaiṇu par inovatīviem P\&I projektiem un publiskā sektora problēmām, kuru risinājumi tiek meklēti.

Ir nepieciešamas iepirkumu procesu veikšanas kultūras izmaiṇas, priekšplānā izvirzot iepirkumu stratēǵisko mērḳi - inovācijas, vides un sociālo problēmu risināšanu, jaunas iespējas uzñēmējiem - un neveltot visu uzmanību tikai iepirkumu procesa administratīvajām un juridiskajām norisēm. Šāda pieeja publiskajiem iepirkumiem ir jāpieņem ne tikai publiskā iepirkuma veicējiem, bet arī iedzīvotājiem, politiķiem, auditoriem. Lai to panāktu, ir nepieciešamas politiskas

11 European Commission. Calls for tenders open: three new Polish pre-commercial procurements. Pieejams: https://ec.europa.eu/digital-single-market/en/news/calls-tenders-open-three-new-polishpre-commercial-procurements [skatīts 08.02.2021.]

12 Publiskais iepirkums pirmskomercializācijas posmā: inovāciju veicināšana ilgtspējīgu kvalitatīvu sabiedrisko pakalpojumu nodrošināšanai Eiropā. ES OV, CE 67/10, 18.03.2010. Pieejams: https://eurlex.europa.eu/legal-content/LV/TXT/?uri=CELEX\%3A52009IP0037 [skatīts 21.02.2021.] 
iniciatīvas, vienota valsts mēroga inovācijas iepirkuma stratēgija un par inovācijas iepirkuma attīstību atbildīga institūcija valsts augstākajā līmenī.

\section{Inovācijas iepirkums}

PIPP ir sagatavošanās pasākums, kas publiskā iepirkuma veicējiem dod iespēju atklāt alternatīvo risinājumu tehnologiskos, pētniecības un izstrādes riskus, pirms tie uzņemas saistības veikt liela apjoma iepirkumu komerciālai izvēršanai. ${ }^{13}$ Kad produkta pirmie izmēǵginājuma paraugi ir izveidoti, tiek organizēta inovācijas iepirkuma procedūra, kurā tos vērtē gan pēc cenas, gan kvalitātes kritērijiem. ${ }^{14}$

Eiropas Komisijas vadlīnijas "Ieteikumi par inovācijas iepirkumu"15 nosaka, ka inovācijas iepirkumam ir jāatbilst vismaz vienam no diviem aspektiem:

- inovācijas procesa iepirkšana, tas ir, P\&I pakalpojuma iepirkums, kas ietver vismaz dal̨eju procesa rezultāta sasniegšanu;

- inovācijas procesa rezultāta iepirkšana.

Inovācijas iepirkuma mērķis ir izvērtēt vairākus alternatīvus risinājumus, lai noteiktu labāko veidu, kā risināt kādu sabiedrības problēmu vai nodrošināt noteiktu pakalpojumu sniegšanu atbilstoši tā brī̌̌a vajadzībām. Inovāciju piedāvājumus nepieciešams salīdzināt pēc vairākiem kritērijiem:

- izmaksu efektivitāte;

- kvalitāte;

- vides ietekme;

- sociālie aspekti;

- biznesa iespējas privātajam sektoram.

Šos kritērijus var un ir nepieciešams pakārtot valsts politikas prioritātēm un plānotajām rīcībpolitikām, piemēram, nevienlīdzības samazināšana, pakalpojuma pieejamības nodrošināšana, apkārtējās vides uzlabošana, $\mathrm{CO}_{2}$ izmešu samazināšana utt.

Inovācijas iepirkuma ieviešanai ir milzīgs potenciāls, lai atbalstītu tehnoloğisko progresu gan valsts, gan privātajā sektorā. Ir nozares, kurās valsts pasūtījums ir noteicošais ienākumu avots (piemēram, cel̦u būve, ūdens attīīšana, pasažieru pārvadājumi, veselības aprūpe). Lìdz ar to inovācijas iepirkums šajās nozarēs ir

PRIMES [7] ZPI inovācijas. Pieejams: http://primes-eu.net/media/12191713/07_inovacijas-ieks-zpi_ gv.pdf [skatits 06.02.2021.]

14 Būtiskākie jautājumi par inovācijas iepirkumu (ES projekts iBuy Interreg Europe.) Pieejams: https://www. interregeurope.eu/fileadmin/user_upload/tx_tevprojects/library/file_1590665261.pdf [skatits 07.02.2021.]

15 Eiropas Komisija. Komisijas paziņojums "Ieteikumi par inovācijas iepirkumu”. C(2018)3051, 15.05.2018. Pieejams: https://ec.europa.eu/transparency/regdoc/rep/3/2018/EN/C-2018-3051-F1-EN-MAIN-PART-1.PDF [skatits 10.12.2020.] 
arī galvenais inovāciju un progresu veicinošais instruments, bez valsts iejaukšanās un stimulēšanas inovāciju attīstība šajās nozarēs būtu krietni stagnējošāka.

Neapšaubāmi, inovācijas iepirkuma veikšana ir daudz sarežğītāka nekā tradicionālā iepirkuma veikšana, tomēr citu valstu pieredze rāda, ka ieguvumi no inovācijas iepirkuma pārsniedz laika un finansiālās izmaksas, tāpēc inovācijas iepirkumu plašu lieto. Eiropas Komisijas vadlīnijās "Ieteikumi par inovācijas iepirkumu"16 norādīts uz šādiem mērķiem inovācijas iepirkuma veikšanā, balstoties uz reāliem piemēriem no dažādām dalībvalstīm:

- piegādāt augstākas kvalitātes sabiedrisku pakalpojumu par optimālām izmaksām;

- risināt parādījušos problēmu;

- modernizēt sabiedriskos pakalpojumus;

- palīdzēt jauniem un inovatīviem maziem uzṇēmumiem attīstīties un augt;

- veicināt inovatīvu risinājumu un produktu tirgus attīstību.

Publisko iepirkumu tiesiskais regulējums paredz daudzveidīgas procedūras un instrumentus, kas izmantojami inovācijas iepirkuma veikšanā, l̦aujot valsts un pašvaldību iestādēm kḷūt par novatorisku produktu un pakalpojumu pirmajiem pircējiem, vienlaikus nodrošinot sabiedrībai nepieciešamu preču un pakalpojumu efektīvu iepirkumu un attīstot jaunas iespējas biznesam. Inovācijas iepirkuma organizēšanas veidu shematisks atainojums redzams 2 . attēlā.

Katra metode atbilst noteikta mērķa sasniegšanai. Atklātā vai slēgtā konkursā, izmantojot funkcionālas tehniskās specifikācijas, atḷaujot piedāvājumu variantu iesniegšanu, pasūtītājs var iepirkt novatoriskus, tirgū jau esošus produktus vai pakalpojumus. Konkursa procedūra ar sarunām l̦auj sarunu ceḷā efektīvāk panākt gatavu risinājumu pielāgošanu publiskā iepirkuma veicēja specifiskām vajadzībām. Konkursa dialogs l̦auj dialogā ar nozari noteikt pasūtītāja vajadzībām piemērotāko risinājumu un to nopirkt. Metu konkursā tiek noteiktas labākās idejas, visbiežāk arhitektūras, pilsētbūvniecības un informācijas sistēmu attīstības jomā. Līgumi ar konkursa uzvarētājiem tiek noslēgti pēc sarunu procedūras. Inovāciju partnerības procedūra l̦auj izstrādāt pilnīgi jaunus produktus un pakalpojumus inovāciju partnerības līguma izpildes gaitā un, ja iegūtais rezultāts atbilst izvirzìtajiem kritērijiem, to nopirkt.

Tādējādi publisko iepirkumu tiesiskais regulējums nodrošina instrumentus inovācijas publiskā iepirkuma veikšanai, tomēr Latvija nevar lepoties ar vērā ņemamiem sasniegumiem inovācijas iepirkumu jomā. Atbilstoši IUB informācijai 2019. gadā pasūtītāji (valsts un pašvaldību iestādes) tikai divos gadījumos bija

16 Eiropas Komisija. Komisijas paziņojums “Ieteikumi par inovācijas iepirkumu”. C(2018)3051, 15.05.2018. Pieejams: https://ec.europa.eu/transparency/regdoc/rep/3/2018/EN/C-2018-3051-F1-EN-MAIN-PART-1.PDF [skatìts 10.12.2020.] 


\section{2. attēls. Inovācijas iepirkuma organizēšanas veidi}

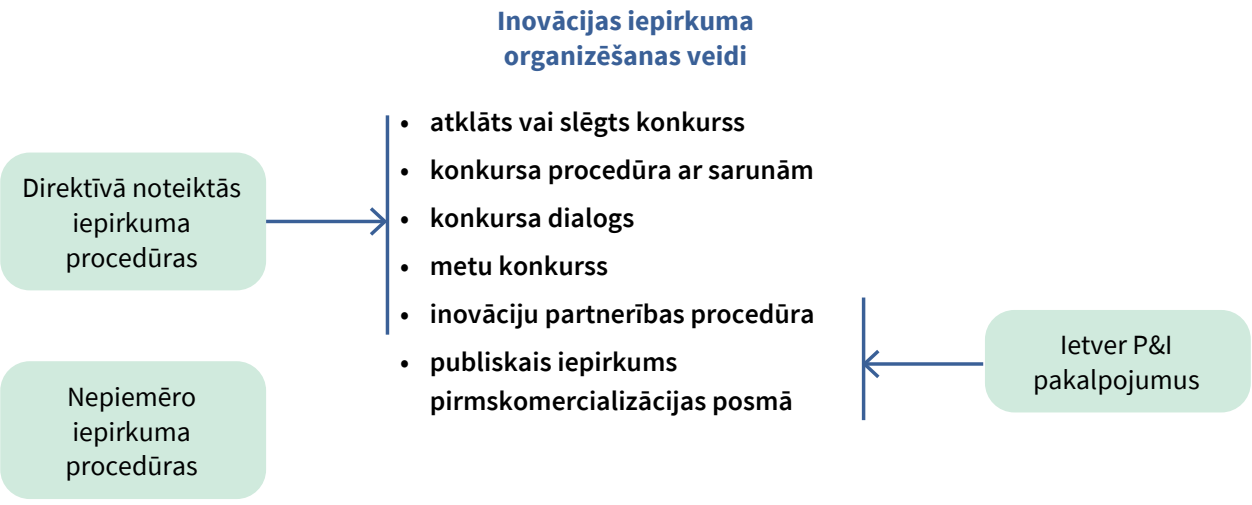

Avots: Dace Gaile.

norādījuši, ka tiek veikts inovācijas iepirkums, 2020. gadā bija septiṇi šādi iepirkumi. Savukārt sabiedrisko pakalpojumu sniedzēji, starp kuriem ir "Latvenergo", "Latvijas dzelzcel̦šs", lidosta "Rīga”, Rīgas brīvostas pārvalde, 2020. gadā nav norādījuši nevienu inovācijas iepirkumu. Attiecīgi netiek piemērotas arī elastīgas, uz inovācijas iepirkumu orientētas iepirkuma procedūras. 2019. gadā konkursa dialoga procedūru skaits bija tikai $0,1 \%$ no kopējā iepirkuma procedūru skaita, konkursa procedūras ar sarunām - 0,4\%, bet inovāciju partnerības procedūra realizēta tikai vienu reizi - 2018. gadā veiktais valsts akciju sabiedrības "Latvijas Valsts meži” iepirkums "Loǵistikas optimizācijas risinātāja izstrāde". ${ }^{17}$

Inovācijas iepirkuma plašākai izmantošanai Latvijā ir vairāki šķēršḷ un riski:

1. Nav vienotas un skaidras izpratnes, kādu iepirkumu var atzìt par inovācijas iepirkumu. Ir izveidojies stereotipisks priekšstats, ka inovācijas iepirkuma rezultātā obligāti tiek radīts pilnīgi jauns un agrāk nebijis pakalpojums vai prece. Taču, kā tas izriet no Eiropas Komisijas vadlīnijām "Ieteikumi par inovācijas iepirkumu"18, arī iepirkums, kura rezultātā tas pats pakalpojums tiek sniegts ar mazākām izmaksām vai - gluži pretēji - izmaksas nav samazinājušās, taču pakalpojums kḷuvis ērtāks klientiem, ir uzskatāms par inovācijas iepirkumu. Tādējādi nav iespējams viennozīmīgi konstatēt, vai

\footnotetext{
17 Iepirkumu uzraudzības birojs. Publikāciju vadības sistēma: Paziṇojums par līgumu. 23.12.2018. Pieejams: https://pvs.iub.gov.lv/show/564326 [skatīts 07.02.2021.]

18 Eiropas Komisija. Komisijas paziņojums “Ieteikumi par inovācijas iepirkumu”. C(2018)3051, 15.05.2018. Pieejams: https:/ec.europa.eu/transparency/regdoc/rep/3/2018/EN/C-2018-3051-F1-EN-MAIN-PART-1.PDF [skatits 10.12.2020.]
} 
un cik bieži tiek veikti inovācijas iepirkumi, nav iespējams precīzi noteikt inovācijas iepirkumu kvantitatīvos rādītājus šobrīd, kā arī veikt to attīstības mērïjumus nākotnē.

2. Nepietiekama publisko iepirkumu veicēju kompetence. Lai veiktu inovācijas iepirkumu, vajadzīgas jaunas iepirkuma veicēju prasmes un zināšanas, spēja identificēt problēmas, kurām nepieciešams novatorisks risinājums, izpratne par inovācijas iepirkumiem piemērojamām procedūrām un kritērijiem. Metodologiskais atbalsts inovācijas iepirkumu veikšanai joprojām ir nepietiekams, nav izstrādāti praktiski ieteikumi, jo īpaši - inovatīvu risinājumu salīdzināšanas kritēriji, piedāvājumu salīdzināšanas un risku novērtēšanas un vadỉbas metodes.

3. Publiskā sektora vēlme izvēèeties iepirkumu procesa risinājumus, kas prasa mazāku cilvēku un laika resursu ieguldījumu. Inovācijas iepirkumam un ieviešanai nepieciešams daudz ilgāks laiks. Organizējot tradicionālo atklāto konkursu, iepirkuma līgumu var noslēgt 3-4 mēnešu laikā, taču PIPP vai inovāciju partnerības līguma ietvaros gaidītā rezultāta sasniegšanai var būt nepieciešami pat vairāki gadi. Inovācijas iepirkumi ir jāplāno laikus, atvēlot pietiekamu laiku konsultācijām ar tirgu un iepirkuma sagatavošanai.

4. Iepirkumu veicēju nevēelēšanās uzṇemties risku. Inovācijas iepirkums ir sarežgìtāks no visiem aspektiem, ieskaitot komplicētas tehniskās specifikācijas, subjektīvākus līguma piešķiršanas kritērijus, piemēram, nepieciešamību salīdzināt un vērtēt novitātes līmeni, funkcionalitāti, sociālos aspektus. Latvijā ir izplatīta bieža valsts iepirkuma rezultātu apstrīdēšana. Ir prognozējams iepirkuma rezultātu apstrīdēšanas aktivitātes pieaugums. Kā rāda citu valstu pieredze, konkurējošo uzṇēmumu pretenzijas inovācijas iepirkumos ir izplatītas, pamatojot tās ar aizdomām par normatīvajos aktos neaț̣autu viena uzṇēmuma interešu lobēšanu. Inovācijas iepirkums pēc būtības ir eksperiments, un tas kā jebkurš eksperiments var arī neizdoties. Šã iemesla dēl diskusijas par inovācijas iepirkumu nenovēršami noved pie jautājuma par valsts pārvaldes tiesībām uz kḷūdu. Viens no aizbildinājumiem, kādēḷ labāk nemēgināt inovācijas iepirkumus, - Valsts kontrole to neatbalsta. Taču patiesībā aiz šā aizbildinājuma slēpjas bailes un nezināšana, kā plānot un vadìt jaunumu ieviešanu, kā izvērtēt un mazināt riskus. Kā norādījusi bijusī valsts kontroliere Elita Krūmiña, "valsts pārvaldē, meklējot jaunus risinājumus, sastopoties ar laika trūkumu, citām neparedzètām problēmām, lielākais izaicinäjums ir nevis paslaucìt kḷ ūdas zem pakläja, bet gan atzìt tās, labot un neatkārtot. Viss jaunais, ko gribam pielietot valsts pārvaldē, nav fikso ideju 
pārbaudes pirmais solis, bet gan plānotas un mērk̦tiecīgas rìcības "apzinātības" pēdējais solis". ${ }^{19}$

5. Netiek koordinēta biznesa vides inovāciju ideju un publiskā sektora problēmu saskare. Latvijas Investīciju un attīstības aǵentūras kompetence aptver inovāciju veicināšanu biznesā, IUB strādā ar publisko iepirkumu veicējiem, taču trūkst saiknes starp biznesa inovāciju idejām un pasūtīāju vajadzību pēc novatoriskiem problēmu risinājumiem. Rezultātā - pasūtîtājiem trūkst inovatīvu ideju, komersantiem - pieprasījuma no publiskā sektora puses.

6. Mediju potenciālā kritika. Var pieḷaut, ka lielāki strīdi publiskajos iepirkumos rezultēsies negatīvākā publiskā sektora atspoguḷšanā medijos. Inovācijas nereti ir saistìtas ar lielām finanšu investīcijām, it īpaši to ieviešanas posmā, kas atmaksājas ilgākā laika periodā, vides vai sociālo inovāciju ieguvums ne vienmēr ir izvērtējams naudas izteiksmē. Diemžēl joprojām publisko iepirkumu rezultātu vērtējumā mediju, uzraugošo institūciju un sabiedrības uztverē dominē noslēgtā līguma finansiālā vērtỉba, un pasūtītāji ne vienmēr spēj argumentēti izskaidrot sabiedrībai inovāciju, zaḷo vai sociālo iepirkumu radīto ieguvumu.

7. Kontrolējošo institūciju neizpratne un kritika. Latvijas valsts pārvaldē uzsvars tiek likts uz pareizu noteikto procedūru ievērošanu, nevis iepirkuma stratēgisko mērḳi un sagaidāmo rezultātu. Arī kontrolējošās institūcijas lielāku uzmanību pievērš tieši precīzai normatīvo aktu prasību izpildei, atstājot darbības būtībai un gala ietekmei otršķirīgu lomu. Inovācijas iepirkumā uzsvars ir tieši uz rezultātu - lai inovācijas iepirkums dotu lielāku labumu kādā no aspektiem, kādai no iesaistītajām pusēm. Dažkārt tas var prasīt normatīvā regulējuma izmaiņas. Ir nepieciešamas kontrolējošo organizāciju domāšanas paradigmas izmain̦as, kas ir vērstas uz inovācijas iepirkuma rezultāta lietderības novērtēěanu.

8. Kultūras aspekts. Kultūrvēsturiskie apstākḷi latvieša raksturu ir izveidojuši ar spēcīgāku konservatīvu noslieci uz kultūru un zinātni, nevis uzņēmējdarbību un inovāciju.

\section{Iespējas inovācijas iepirkuma attīstībai}

Eiropas Komisija, pamatojot inovācijas iepirkumu nozīmi, norāda, ka publiskā iepirkuma mērḳis ir ne tikai valsts pārvaldes pamatvajadzību apmierināšana, bet arī budžeta līdzekḷ izlietojuma lietderība, kas īstenojas kā iepirkuma

19 Krūmiņa, E. Mans draugs - valsts kontrolieris. Pieejams: https://www.lrvk.gov.lv/lv/aktualitates/ mans-draugs-valsts-kontrolieris [skatīts 02.04.2021.] 
rezultātā iegūta labākā pievienotā vērtība (kvalitāte, izmaksas, vides un sociālā ietekme) un jaunu uzṇēmējdarbības iespēju attīstīšana.

Inovācijas iepirkums kā viens no inovāciju attīstības instrumentiem norādīts vairākos Latvijai nozīmīgos stratēǵiskās plānošanas dokumentos. Latvijas ilgtspējīgas attīstības stratēgijā līdz 2030. gadam uzsvērta inovācijas iepirkuma programmas nepieciešamība: "Valsts un pašvaldības institūcijām būtu jāatvēl finanšu līdzekḷi, lai iepirktu īpaši to vajadzībām radītus jaunus inovatīvus pakalpojumus un produktus. Šādā veidā pārvaldes institūcijas uzñemtos katalizatora lomu jaunrades un inovatīvas uzṇēmējdarbības vides veicināšanā.”

Nacionālajā attīstības plānā 2021.-2027. gadam atzìts, ka publiskajam sektoram jāuzņemas aktīva loma kā inovācijas veicinātājam un pasūtītājam (tostarp caur inovatīvu iepirkumu).

Nacionālās industriālās politikas pamatnostādnēs 2021.-2027. gadam kā viena no aktivitātēm norādīta inovācijas iepirkuma izpratnes veicināšana un normatīvo aktu izvērtēšana inovāciju jomā. Vēl konkrētāk nepieciešamā rīcība noteikta Viedās specializācijas stratēǵijas (RIS3) pirmajā monitoringa ziṇojumā ${ }^{20}$ - izstrādāt inovāciju partnerības procedūras iepirkuma praktiskās piemērošanas vadlīnijas un iestrādāt inovācijas iepirkuma prasību visās atbilstošajās Viedās specializācijas stratēgijas (RIS3) īstenošanas programmās.

2020. gada 26. maijā Ministru kabinets apstiprināja Latvijas ekonomikas atjaunošanas plānu "Stratēǵija Latvijai Covid-19 krīzes radīto seku mazināšanai"21, lai pārvarētu Covid-19 vīrusa radīto krīzi Latvijā, kā arī pēc iespējas ātrāk atgrieztos ne tikai pirmskrīzes perioda līmenī, bet arī to pārsniegtu. Stratēéija ietver 5 rīcības virzienus - cilvēkkapitāls, inovācija, biznesa vide eksportspējai, finanšu pieejamība un infrastruktūra. Pārorientācijas periodā (2021.-2022. gadā) īstenojami pasākumi, kas, n,emot vērā Covid-19 krīzes radītās izmaiṇas globālajā ekonomikā, kā arī izmantojot Latvijas tautsaimniecības priekšrocības un izaicinājumus, rada jaunas iespējas uzṇēmējiem un iedzīvotājiem, uzsvaru liekot uz inovāciju, digitālo transformāciju, mūžizglītību un orientējoties uz ekonomikas strukturālām pārmaiṇām, mērḳtiecīgi pielāgojot valsts atbalsta mehānismus. Izaugsmes fāze - sākot no 2023. gada un turpmāk īstenojami pasākumi tautsaimniecības transformācijā, kas balstīti preču un pakalpojumu eksporta dinamiskā attīstībā, nodrošinot tautsaimniecības izaugsmi caur produktivitātes pieaugumu,

20 Informatīvais ziņojums "Viedās specializācijas stratēgijas monitorings". Pieejams: https://www.izm. gov.lv/sites/izm/files/media_file/ris3_pirmais-monitoringa-ziojums_20181.pdf [skatīts 07.02.2021.]

21 Latvijas Republikas Ministru kabinets. Informativais ziṇojums "Stratēgija Latvijai Covid-19 krīzes radīto seku mazināšanai”. Pieejams: http://tap.mk.gov.lv/lv/mk/tap/?pid=40487682\&mode=mk\&date $=2020-05-26$ [skatìts 08.02.2021.] 
automatizāciju, digitālo transformāciju, atbalstu uzṇēmumu izaugsmei un strauji augošām nozarēm un ekosistēmām. ${ }^{22}$

ESAO savā ziṇojumā ${ }^{23}$ arī norāda, ka valstu valdībām, lai īstenotu veiksmīgu inovācijas iepirkumu, ir:

- publiski jārunā par inovāciju pozitīvo devumu un labajiem rezultātiem;

- jāveic aktīva horizontāla un vertikāla uzdevumu koordinācija iestādēs;

- jādemonstrē politiskā līderība un politiskās apn,emšanās;

- jāstiprina cilvēkresursu kapacitāte un zināšanas;

- jāveicina jauna darba kultūra, kas rosinātu inovatīvāku ikdienas domāšanu un jaunas idejas;

- jāveicina sadarbība starp dažādām struktūrvienībām publiskā iepirkuma procesā.

Eiropas Komisija iesaka šādas rekomendācijas, kā veicināt inovācijas iepirkuma izmantošanu ${ }^{24}$ :

- pārskatīt trešo valstu, kas nav Eiropas Savienības dalībvalstis, pieeju tirgum;

- vadīt un koordinēt reǵionālā, nacionālā un pārrobežu līmenī kopīgus inovācijas iepirkumus;

- pārskatìt procedūras, lai izvairītos no nevajadzīgas konkurences starp vienas valsts regioniem un starp dalïbvalstīm;

- izmantot sinergiju starp iepirkumu un ekonomikas attīstību, agrīna vajadzību apzināšana var vadīt un paātrināt inovāciju;

- labās prakses metodikas izmantošana;

- izmantot tirgus analīzi, lai izprastu tirgus iespējas un novērstu negodprātīgu piegādātāju rīcību;

- izveidot juridisku pamatojumu inovācijas iepirkuma procedūrām;

- izmantot atvērtos avotus un datus.

Kā jau tika minēts, viens no problēmjautājumiem inovācijas iepirkumos ir risks, ka iepirkuma līguma rezultātā inovācija netiek radīta. Atkarībā no līgumslēdzējas iestādes, to vajadzībām un tirgus sektora būs piemēroti dažādi pasākumi un procedūras. Tomēr pastāv daži kopīgi pamatprincipi, kurus nepieciešams

22 Ekonomikas ministrija. MK apstiprina stratēǵiju Latvijai Covid-19 krīzes radīto seku mazināšanai. Pieejams: https://www.em.gov.lv/lv/jaunums/mk-apstiprina-strategiju-latvijai-covid-19-krizes-raditoseku-mazinasanai [skatīts 08.02.2021.]

23 OECD. Public Procurement for Innovation: Good Practices and Strategies. Pieejams: https://read.oecd-ilibrary.org/governance/public-procurement-for-innovation_9789264265820-en\#page1 [skatīts 03.02.2021.]

24 European Commission. WEBINAR - Opportunities to tackle the COVID-19 Crisis through Innovation Procurement. Pieejams: https:/eafip.eu/events/webinars/opportunities-to-tackle-the-covid-19-crisisthrough-innovation-procurement/ [skatits 06.02.2021.] 
ievērot, lai mazinātu inovāciju ieviešanas riskus un noritētu veiksmīga inovācija publiskajā iepirkumā. Šie pamatprincipi tiek apskatīti tabulā. ${ }^{25,26}$

\section{Tabula. Pamatprincipi, kurus nepieciešams ievērot, lai mazinātu inovāciju ieviešanas riskus}

Pamatprincips

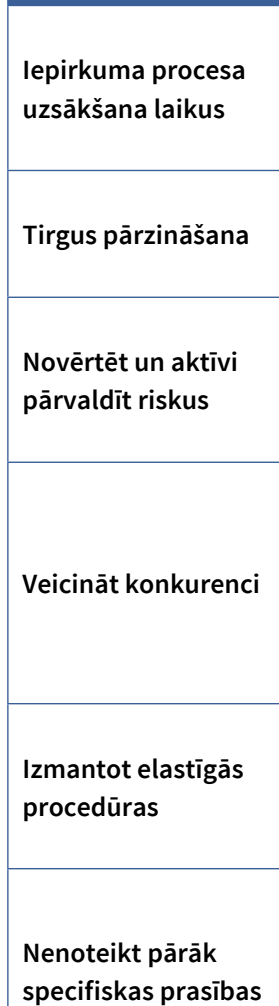

Nepieciešamības pamatojums

Kvalitatīvai inovācijas iepirkuma procesa organizēšanai nepieciešams ilgāks laiks, tāpēc ir svarīgi plānot darbības laikus, saglabājot pietiekami daudz laika, lai rūpīgi novērtētu un izprastu savas vajadzības un laikus informētu tirgu par saviem nodomiem.

Būtiska nozīme ir padzilıinātai izpratnei par inovatīva produkta vai pakalpojuma potenciālo piegādes k̦ēdi, un tirgus izpēte un iepriekšēja apspriešanās ar tirgu ir svarīgi rīki, lai saṇemtu kvalitatīvu piedāvājumu un galarezultātus.

Visām inovācijas iepirkuma procedūrām ir kopīgi ieviešanas riski, un tie regulāri jānovērtē un jāvada. Jāizveido projekta vadības grupa, kas var koordinēt procesu un pārvaldīt risku, kad tas rodas. Šāds risinājums minimalizētu riskus, kad publiskais finansējums tiek izlietots nelietderīgi un nesasniedz rezultātu.

Publiskā iepirkuma direktīvas ${ }^{27,28}$ piel̦auj izņēmuma gadījumos atkāpties no vispārīgā noteikuma par konkurences nodrošināšanu, tomēr konkurence var palīdzēt nodrošināt labāku piedāvājumu un iegūt labākus rezultātus. Publicējot iepriekšēju paziņojumu par iepirkumu un veicot relatīvi nelielus ieguldījumus informācijas publiskošanā, piemēram, reklāmas tīmeklvietnēs, var piesaistīt plašāku konkurentu loku.

Inovāciju partnerība, konkursa dialogs vai konkursa procedūra ar sarunām ļauj vairāk mijiedarboties ar tirgu, lai uzlabotu piedāvājumu. Tomēr, lai tās îstenotu, nepieciešams papildu laiks, tāpēc, izvēloties elastīgu vairāku posmu procedūru, ir svarīgi apsvērt iepirkuma ietekmi uz pieejamiem laika un cilvēkresursiem.

Uz darbības rezultātiem balstītās vai funkcionālās specifikācijas l̦auj piegādātājiem/pakalpojuma sniedzējiem elastīgi piedāvāt un ieviest inovatīvus risinājumus. Labi līdzsvarota specifikācija l̦auj tirgum precīzi saprast, ko vēlas pasūtītājs, vienlaikus nediktējot konkrētus veidus, kā rezultāts būtu sasniedzams.

25 Innovation Procurement Platform. Implementing innovation procurment. Pieejams: https://innovationprocurement.org/implementing-innovation-procurement/ [skatìts 03.02.2021.]

26 IISD. Three Key Challenges to Innovative Public Procurement (by Casier, L., 11.06.2018.). Pieejams: https://www.iisd.org/articles/three-key-challenges-innovative-public-procurement [skatīts 03.02.2021.]

27 Eiropas Parlamenta un Padomes Direktiva 2014/24/ES (2014. gada 26. februāris) par publisko iepirkumu un ar ko atcel, Direktīvu 2004/18/EK.

28 Eiropas Parlamenta un Padomes Direktīva 2014/25/ES (2014. gada 26. februāris) par iepirkumu, ko îsteno subjekti, kuri darbojas ūdensapgādes, enerḡētikas, transporta un pasta pakalpojumu nozarēs, un ar ko atcel Direktīvu 2004/17/EK. 


\begin{tabular}{|c|c|}
\hline $\begin{array}{l}\text { Informāciju padarīt } \\
\text { vispārpieejamu }\end{array}$ & $\begin{array}{l}\text { Ja iespējams, ir jāveic atklāta informācijas apmaiņa tiešsaistē, l̦aujot pētniekiem } \\
\text { un uzņēmumiem domāt par iespējamiem risinājumiem, pirms vēl tiek izsludināts } \\
\text { iepirkums. Veicot inovācijas iepirkumu, korekts informācijas kvantitātes, } \\
\text { kvalitātes un laika ietvars var palīdzēt izprast uzṇēmumu/organizāciju pašreizējo } \\
\text { problemātiku, kā arī iespējamos risinājumus. }\end{array}$ \\
\hline $\begin{array}{l}\text { Veikt savstarpējo } \\
\text { vienošanos un } \\
\text { izveidot intelektuālā } \\
\text { īpašuma stratēǵiju }\end{array}$ & $\begin{array}{l}\text { Lai apzinātu vissvarīgākās inovācijas priekšrocības, netēēējot nevajadzīgi } \\
\text { līdzekḷus par tiesībām un lietošanas iespējām, kas praktiski netiks izmantotas, } \\
\text { pasūtītājam būtu jāizstrādā stratēḡija par intelektuāāā īpašuma tiesībām, kurā } \\
\text { ņemti vērā tā iegāāāā produkta vai pakalpojuma iespējamie pielietojumi } \\
\text { nākotnē. Aplūkojamiem jautājumiem būtu jāietver iestādes turpmākā iespēja } \\
\text { mainīt pakalpojumu sniedzējus un paredzēt, ka projekta veikšanu varētu aţ̦aut } \\
\text { arī citiem pakalpojuma lietotājiem. }\end{array}$ \\
\hline Pārvaldīt līgumus & $\begin{array}{l}\text { Līgums un tā pārvaldība nosaka inovācijas iepirkuma galarezultātu. Ir } \\
\text { jābūt skaidriem turpmāko līguma posmu nosacījumiem, kā arī galvenajiem } \\
\text { darbības rādītājiem, stimuliem un sodiem, licencēšanas tiesībām, izbeigšanas } \\
\text { nosacījumiem, atjaunošanas noteikumiem, risku apdrošināšanai un atlīdzības } \\
\text { apjomam un kārtībai. }\end{array}$ \\
\hline
\end{tabular}

Lai Latvijā ievērotu Eiropas Komisijas izteiktās rekomendācijas un tabulā aplūkotos labās prakses pamatprincipus, inovācijas iepirkumus būtu iespējams organizēt atbilstoši spēkā esošajiem normatīvajiem aktiem, tomēr, lai pilnībā novērstu piemērojamā regulējuma interpretāciju riskus, mazinātu identificēto šķēršlu ietekmi un kopumā veicinātu šā iepirkumu veida izmantošanu, būtu ieteicams veikt vairākus pasākumus.

Atbilstoši Eiropas Komisijas ieteikumiem ${ }^{29}$ jāizveido vienota valsts mēroga programma (stratēgija) stratēgiskā iepirkuma attīstībai (inovācijas iepirkums, zaļais publiskais iepirkums, sociāli atbildīgs iepirkums), ņemot vērā, ka inovācijas biznesā, valsts pārvaldē, vides aizsardzībā, sociālajā jomā bieži veido vienotu veselumu un visu šo jomu sinergija var dot vislabākos rezultātus. Skaidram politikas redzējumam, kuru stratēgiskajā iepirkumā iesaistītajām iestādēm un profesionāḷiem sniedz politiskā līmenī, ir izšḳkirīga nozīme, jo tas nodrošina rīcībai nepieciešamo pilnvarojumu. Ja politikas redzējumu pavada skaidra informēšanas kampaṇa un tas tiek atbalstîts ar ilgtermiña budžeta saistībām, tam ir lielākas izredzes gūt panākumus. Stratēgisko iepirkumu, tostarp inovācijas iepirkumu programmas (stratēóijas), izstrāde un mērḳtiecīga virzība var strauji veicināt inovāciju attīstību Covid-19 krīzes periodā un pēckrīzes periodā.

Stratēgiskā iepirkuma attīstîbas programmai būtu jāietver inovācijas publiskā iepirkuma veicināšanas pasākumi:

29 Eiropas Komisijas paziņojums "Kā Eiropas interesēs panākt labāku iepirkuma darbību Eiropā". Pieejams: https://eur-lex.europa.eu/LexUriServ/LexUriServ.do?uri=COM:2017:0572:FIN:LV:PDF [skatits 08.02.2021.] 
- institucionālais ietvars - koordinējoša centra noteikšana, inovācijas publiskā iepirkuma ekosistēmas izveidē, kas nodrošinātu publiskā sektora iepirkumu veicēju, uzņēmēju un pētnieku sadarbību;

- finansiāls atbalsts - lai publiskais pasūtītājs varētu plānot inovācijas iepirkumu, tam ir nepieciešams budžeta finansējums gan inovācijas iegādei, gan iepirkuma sagatavošanai un organizēšanai. ES ieteikumos par inovācijas iepirkumu kā viens no atbalsta instrumentiem ir minēta iespēja noteikt zemāku vai pat $0 \%$ PVN likmi pētniecības un izstrādes pakalpojumu publiskajam iepirkumam, kas rada izaugsmi un darba vietas. Finansiālais atbalsts nepieciešams arī mazajiem un vidējiem uzñēmumiem un jaunuzṇēmumiem, lai sagatavotu piedāvājumus citu ES dalībvalstu pirmskomercializācijas pētniecības un izstrādes projektos ${ }^{30}$;

- pasākumi iepirkuma veicēju kompetences stiprināšanai;

- izmaiñas normatīvajos aktos - tostarp precizējot tiesisko regulējumu inovāciju partnerības procedūrai, kā arī modernizējot Autortiesību likumu. Būtu jāizstrādā inovācijas iepirkuma vadlīnijas, kas ietvertu:

- skaidri saprotamu inovācijas iepirkuma definīciju;

- pārskatu par inovāciju atbalsta politikas dokumentiem un inovācijas iepirkuma tiesisko regulējumu;

- inovāciju plānošanas procesa, risku izvērtējuma detalizētu aprakstu;

- ieteikumus konsultācijām ar privāto sektoru;

- ieteikumus kopīgu (centralizētu) un pārrobežu inovācijas iepirkumu organizēšanai;

- izmantojamo iepirkuma procedūru shēmas un aprakstus;

- izmantojamo rīku un metožu aprakstu - inovāciju novērtēšanas kritērijus, alternatīvu variantu salīdzināšanas metodes;

- iepirkuma dokumentu paraugus, tostarp tipveida iepirkuma līgumus ar intelektuālā īpašuma izmantošanas klauzulām;

- èrti lietojamus aprites cikla izmaksu, ilgtermiṇa ieguldījumu un inovāciju radīto ieguvumu aprēķinu kalkulatorus, risku novērtējumu matricas;

- labas prakses paraugu aprakstus ar to juridisko pamatojumu;

- inovācijas iepirkumu statistikas apkopošanas kārtību;

- informācijas par inovācijas iepirkumiem iegūšanas avotus, atbalsta rīkus, kontaktpunktus.

Pēc vadlīniju izstrādes būtu jāsagatavo mācību programma un jāorganizē iepirkumu veicēju apmācība. Daḷa apmācību moduḷu varētu tikt izveidota 
e-mācību modulu veidā, šāda pieredze jau ir izveidojusies Valsts administrācijas skolā un Iepirkumu uzraudzības birojā.

Lai pārbaudìtu un pierādītu vadlīniju praktisko lietderību, būtu mērḳtiecīgi jāīsteno daži pilotprojekti atšķirīgam inovāciju līmenim, piemērojot dažādas iepirkuma procedūras un metodes. Sākotnēji varētu orientēties uz nozarēm un projektiem, kuros inovāciju var īstenot vienkāršāk un kur tai var būt vislielākā ietekme. Kā pilotprojektu platformas varētu tikt izmantotas jau izveidojušās inovāciju ekosistēmas, kā arī valsts un pašvaldību komercsabiedrību zināšanas un finanšu resursi. Pilotprojektu īstenošanu varētu koordinēt Latvijas Investīciju un attīstības ağentūra un to realizēšanā iesaistìt valsts kapitālsabiedrības, piemēram, AS "Latvijas Valsts meži”, VSIA "Latvijas Valsts celì”, AS "Latvenergo", VAS “Latvijas dzelzceľ̦̌”, VAS “Starptautiskā lidosta "Rīga"”, VAS "Valsts nekustamie īpašumi".

Lai izveidotu inovācijas iepirkuma vienotu kompetences centru, būtu jāizvērtē, vai šis pienākums varētu tikt uzdots kādai no esošajām institūcijām, piemēram, paplašinot un nostiprinot Latvijas Investīciju un attīstības aǵentūras funkcijas un kompetenci.

Lietderīgi būtu izveidot arī starpnozaru konsultatīvu un koordinējošu institūciju - Inovācijas iepirkumu padomi, kas apvienotu nozaru ministriju, citu valsts pārvaldes institūciju, zinātnisko institūciju, pašvaldību un privātā sektora pārstāvjus. Padomes mērķis būtu noteikt galvenos inovācijas iepirkuma virzienus atbilstoši politikas plānošanas dokumentos noteiktajām prioritātēm, dizainēt kopīgus pilotprojektus, plānot atbalsta pasākumus un finansējumu, organizēt diskusijas un hakatonus, lai identificētu idejas PIPP attīstībai, organizēt starptautisko sadarbību u. tml. Lai nesadrumstalotu inovāciju attīstības pasākumu koordināciju, Inovācijas iepirkumu padomi varētu veidot kā Latvijas Pētniecíbas un inovācijas stratēgiskās padomes apakškomisiju.

Daudzi inovācijas iepirkuma procesi, kurus veic atsevišķi pasūtītāji, nodrošina labus risinājumus, taču tie tiek izbeigti pēc izmēginājuma vai prototipa izstrādes posma, jo viens pircējs nerada pietiekamu pieprasījumu. Risinājums būtu - publiskie pircēji ar līdzīgām interesēm un vajadzībām (piemēram, apvienojoties vairākām ārstniecỉbas iestādēm, lai risinātu slimnīcu darba optimizācijas problēmas Covid-19 krīzes apstākḷos, vairākām sociālās aprūpes iestādēm, meklējot senioru dzīves kvalitātes uzlabošanas risinājumus, vairākām pašvaldībām viedo pilsētu projektu attīstībā) apvieno spēkus un aicina tirgu piedāvāt risinājumu, kas tiem l̦autu sasniegt kopīgo mērḳi. Kopīgie projekti iespējamajiem piegādātājiem sniedz paredzamību, skaidrību un - kas īpaši svarīgi - komercializācijai un sērijveida ražošanai 
nepieciešamo apjomu. Šādas sadarbības mērḳtiecīga plānošana, kopīgu pilotprojektu īstenošana varētu kḷūst par būtisku inovācijas iepirkumu attīstības katalizatoru.

$\checkmark \quad$ Kā inovācijas iepirkumus kavējoši faktori tiek minēta nepietiekama informācija par iespējām piedāvāt novatoriskas idejas publiskajos iepirkumos, ideju trūkums inovācijas iepirkumam, informācijas sadrumstalotība. Šo problēmu varētu mazināt vienota interneta portāla izveide, piemēram, Latvijas inovāciju portāla attīstîba, iekḷaujot tajā arī informāciju par inovācijas iepirkumiem. Portālā jānodrošina iespēja publicēt pasūtītāju ierosinātas problēmas, kurām nepieciešams risinājums, un uzṇēmēju un zinātnisko institūciju piedāvātus novatoriskus risinājumus.

\section{Secinājumi}

Tiesiskajā regulējumā Latvijā ir pilnībā pārņemtas ES publisko iepirkumu direktīvās paredzētās iespējas inovācijas iepirkuma veikšanai. Galvenie šķēršşli inovācijas iepirkuma veikšanai ir nepietiekams metodiskais atbalsts un izpratne par sarežgìitu iepirkuma procedūru piemērošanu (konkursa dialogs, inovāciju partnerības procedūra), inovāciju ideju trūkums un bailes no neveiksmēm. Nav valsts mēroga koordinācijas un programmas stratēgiskā, tostarp inovāciju, iepirkuma attīstībai, bet šāda programma ir vitāli nepieciešama. Nepieciešama ir arī platforma informācijas apmaiṇai par publiskā sektora problēmām un inovatīvām izstrādēm privātajā sektorā.

Inovāciju veicināšanas nolūkos ir jāpanāk uztveres maiṇa publiskā iepirkuma vērtējumā no uzsvara uz juridiskajiem aspektiem un zemākās cenas uz stratēgisko mērķu sasniegšanu. 